\title{
Impacts of the removal of invasive Carpobrotus on spider assemblage dynamics
}

\author{
Julie Braschi ${ }^{1,2,3}$ (D) Ophélie Hélard ${ }^{1}$. Christophe Mazzia ${ }^{1}$ (D) Pierre Oger ${ }^{4}$. \\ Philippe Ponel ${ }^{1}$ (D) . Elise Buisson ${ }^{1,3}$ (D)
}

Received: 10 April 2020 / Revised: 8 December 2020 / Accepted: 12 December 2020 /

Published online: 6 January 2021

\begin{abstract}
Mediterranean island biodiversity is threatened by invasive plants, especially by Carpobrotus species. Invasive plant control is a major management tool for the restoration of invaded areas, but the effect of Carpobrotus removal on arthropods is poorly understood. In this study, we evaluate how spider assemblages are influenced by Carpobrotus removal on a Mediterranean island. A Carpobrotus patch was manually uprooted, followed by litter removal between November 2011 and February 2012. A nearby site with native matorral vegetation and no management was also studied. Spider communities were sampled using pitfall traps two years before removal (2010-2011), and then every two years after, between 2013 and 2019. Vegetation at the Carpobrotus site changed from a dense mat of Carpobrotus to a diverse halophilous grassland with some chamaephytes, while it remained stable in the matorral. Spider species richness increased significantly after removal and significant changes in assemblage composition were observed between pre- and post-removal years with a high turnover rate, while spider assemblages remained relatively stable in the matorral. Litter-dwelling spiders with trap strategies like Oecobius navus were the most reduced by Carpobrotus removal, while foliage-dwelling spiders which forage on plants like Xysticus benefited the most, likely due to vegetation opening and diversification of microhabitats. The increase in bare ground cover favoured Aelurillus v-insignatus, Nomisia celerima and Zodarion elegans, which are characterized by an affinity for dry sunny environments. Invasive Carpobrotus removal induced a rapid change (7 years) in spider assemblages as well as an enrichment in taxonomic and functional diversities.
\end{abstract}

Keywords Arachnids · Conservation management · Island · Invasive plant removal · Mediterranean type ecosystems $\cdot$ Restoration

Communicated by Nigel E. Stork.

Julie Braschi

Julie.Braschi@imbe.fr

Extended author information available on the last page of the article 


\section{Introduction}

Biological invasions by non-native plant species is a major direct driver of environmental change in ecosystems worldwide, causing declines in native species diversity, alterations in nutrient cycling and bottom-up impacts on higher trophic levels (Levine et al. 2003; Vilà et al. 2011; D’Antonio and Flory 2017). Island ecosystems in the Mediterranean Basin are particularly vulnerable to plant invasive species (Hulme et al. 2008). Indeed, Walsh et al. 2012 predict that islands with both a relatively high percentage of invasive species and many threatened or endemic species are more at risk. Island communities may also be more vulnerable to invasions due to vacant niches (Whittaker et al. 2017). Moreover, small islands $(<1000 \mathrm{ha})$ are more vulnerable than large ones because of the disproportionate effects of invasive species on the local carrying capacity of the ecosystems (Médail 2017).

Species of the genus Carpobrotus (ice plant) are among the most harmful invasive plants. They have strong negative impacts on biodiversity on both local and global scales (Vilà et al. 2006; Hulme et al. 2008; Celesti-Grapow et al. 2016). Carpobrotus acinaciformis, Carpobrotus edulis and their hybrids are mat-forming succulent plants (Aizoaceae) native to South Africa, introduced as ornamental plants and for soil stabilization purposes in many coastal regions of the world (Campoy et al. 2018). They form quasi-monospecific mats that exclude native species by competition, homogenize the landscape by eliminating micro-habitats, and modify soil properties (e.g. increasing soil salinity and producing allelopathic substances that inhibit the germination of native species seeds) (Conser and Connor 2009; Santoro et al. 2011; Novoa et al. 2012; Novoa and González 2014; Badalamenti et al. 2016; Vieites-Blanco and González-Prieto 2018; Campoy et al. 2018).

Invasive plant control is a major management tool for the restoration of invaded areas, but there has been limited experimental tests of the effects of invasive control (Kettenring and Adams 2011). Ideally, monitoring should be implemented before and after invasive plant control, not just on plant communities, but also on other taxa and different trophic levels to develop better guidelines for their management (Blossey 1999). Species of the genus Carpobrotus are being controlled or eradicated in many areas of the world using a wide variety of tools (e.g. uprooting, herbicide or biological control; Campoy et al. 2018). However, detailed monitoring is uncommon: Chenot et al. (2018) studied the effect of Carpobrotus removal on soil erosion and native vegetation by performing experiments in small plots over a short period; Krebs et al. (2015) and (Buisson et al. 2020) studied the effect of Carpobrotus removal on native plant recolonization on a 1-ha area, over several years.

While the effects of Carpobrotus on arthropod assemblages (Palmer et al. 2004; Orgeas et al. 2007; Rodríguez et al. 2019) and on the pollination of native species (Moragues and Traveset 2005; Bartomeus et al. 2008) have been studied by comparing areas with and without Carpobrotus, the effect of Carpobrotus control on arthropods is poorly known (Knapp 2014). However, despite the prominent role of spiders in most ecosystems, these invertebrates are still notably endangered as well as underrepresented in current conservation efforts (Branco and Cardoso 2020). The introduction of exotic species, including other spiders, animals, plants or fungi, may have direct or indirect impacts on native spiders, moreover for island populations (Borges et al. 2020).

Among arthropods, spiders are well studied in the context of habitat variations (Marc et al. 1999; Uetz et al. 1999; Pearce and Venier 2006; Buchholz 2010; Gerlach et al. 2013) notably because (i) they are taxonomically well known, abundant and inhabit a wide array of spatial and temporal niches (Kremen et al. 1993); (ii) their ecology is widely studied and they respond significantly to abiotic and biotic variations, disturbance and management, 
even on small scales (Bell et al. 2001), and (iii) they can be easily collected using standardized sampling methods (Wise 1993). Consequently, spiders are valuable and useful to monitor habitat management and restoration practices (Pétillon et al. 2006; Cristofoli et al. 2010; Borchard et al. 2014; Hacala et al. 2019; Smith DiCarlo and DeBano 2019).

The aim of this study was to evaluate how spider assemblages were influenced by Carpobrotus removal on a small Mediterranean island. In particular, the objectives were to determine which spider species were the most impacted by the removal of this non-native plant. Sampling was performed 2 years before Carpobrotus removal and every 2 years after removal, over a 7 year period. We sampled (i) a site with a dense mat of Carpobrotus prior to removal and (ii) a site of native matorral vegetation (with no Carpobrotus removal). The latter site was not chosen as a restoration target, but rather as a local reference for normal variation in spider communities between years. We expected to find an enrichment in taxonomic and functional diversities of spider assemblages after Carpobrotus removal, depending on the relative success of vegetation recovery.

\section{Methods}

\section{Study area}

The study was conducted on Bagaud Island, a 59-hectare islet forming part of Hyères archipelago in the National Park of Port-Cros on the Mediterranean coast of France $\left(43^{\circ}\right.$ $00^{\prime} \mathrm{N}^{\circ} 21^{\prime} \mathrm{E}$ ) (Ruffino et al. 2015). Bagaud Island is a strict biological reserve with prohibited access to the public. The island is $7.5 \mathrm{~km}$ from the coast and ca. $500 \mathrm{~m}$ from the main island of Port-Cros. The mean annual temperature is $16.6^{\circ} \mathrm{C}$ with a mean annual precipitation of $724 \mathrm{~mm}$ (Porquerolles weather station, period from 2010 to 2019) and highly variable inter-annual rainfall, typical of the Mediterranean climate. The main habitat types are (i) high matorral (with trees, including Pinus halepensis, Erica arborea) (ii) low matorral (without trees, including Cistus spp., Pistacia lentiscus, etc.) and (iii) coastal vegetation characterized by halophilous species, each constituting rich native plant communities (Ruffino et al. 2015). A total of 2 ha of Carpobrotus was spread in various patches on the island as well as on the cliffs; the biggest patch, ca. 0.5 ha, was where this study was carried out.

\section{Study sites}

The two study sites had similar elevation, slope and soil type, approximately ca. $400 \mathrm{~m}$ apart:

(i) the Carpobrotus removal site is a ca. 0.5-ha patch of vegetation highly invaded by Carpobrotus spp., introduced on Bagaud Island in the mid-nineteenth century. Carpobrotus was manually uprooted between November 2011 and February 2012, producing 20 tons of Carpobrotus material, left in piles on Bagaud Island [the biomass was not exported to prevent the dissemination of fruits (Chenot et al. 2018)]. Regular control of the treated areas with systematic uprooting of new sprouts and shoots were implemented over the seven following years to ensure success (Ruffino et al. 2015).

(ii) the matorral site is a low matorral community without Carpobrotus, characterized by Cistus monspeliensis, Cistus salviifolius, E. arborea, P. lentiscus, Phillyrea angus- 
tifolia, and Smilax aspera. Vegetation dynamics are slow at this site and this plant community was considered to be stable over the study period (Buisson et al. 2020). We suspect that vegetation of the Carpobrotus removal site will develop towards the community structure of this matorral site, but this was not expected to happen within 7 years. This site will be therefore used as a reference for the Carpobrotus removal site only in a much longer term than in this study period. For this study, it constituted a site where no management had occurred and where arthropod assemblages are only affected by natural variations.

\section{Sampling design}

Spiders were sampled using pitfall traps $(10 \mathrm{~cm}$ deep and $5 \mathrm{~cm}$ diameter) filled with ethylene-glycol and a few drops of detergent. Pitfall traps were active continuously from midApril to late-June, and were emptied every 3 weeks resulting in three sampling periods. For subsequent analyses, pitfall trap catches in each trap over the three sampling periods were pooled. On each site, ten traps spaced $5 \mathrm{~m}$ apart were placed on a transect geolocated with GPS and marked by stakes. Traps were sampled 2 years before Carpobrotus removal $(2010,2011)$, and then every 2 years thereafter $(2013,2015,2017,2019)$. Because we only sampled spiders with pitfall traps, we expected to catch more ground-dwelling spiders comparative to web-spinning species (sweep net sampling) or small litter spiders (Berlese sampling). We chose this sampling technique so that it would be the most consistent between years (i.e. litter being highly variable since Carpobrotus litter was removed with Carpobrotus). Spiders were first sorted by morphospecies (Oliver and Beattie 1996) then identified with the help of Roberts (2014), Nentwig et al. (2020), and Oger (2020). Only adult spiders were included in the analysis. Due to the difficulty of taxonomic identifications, some adults were pooled: by families (Dictynidae, Linyphiidae and Theridiidae) or genera (Euophrys and Xysticus) (see “Appendix 1").

\section{Environmental variables}

The total percent cover of the vegetation, the percent covers of each native shrub, all herbaceous species, Carpobrotus alone, bare ground and litter were visually estimated in three $100 \mathrm{~m}^{2}$ plots (5.64 m circles). Plots were placed at each end of each transect as well as in the middle of the transects. We described each site using cover classes $(i<1 \%, 1: 1-10 \%$, 2: $11-25 \%, 3: 26-50 \%, 4: 51-75 \%, 5:>76 \%)$ before $2010-2011$ and after $(2013,2015$, $2017,2019)$ removal. For the following statistical tests, the mean median value of each cover class was used $(i=0.5 \%, 1=5.5 \%, 2=17.5 \%, 3=37.5 \%, 4=62.5 \%, 5=87.5 \%$ ). Plant species lists were generated in each plot to estimate plant species richness.

Minimum and maximum daily temperatures and daily rainfall data were obtained from the Porquerolles weather station and an average daily temperature was calculated.

\section{Functional traits}

Six functional traits of adult spiders were selected and assigned to species based on the literature. (i) Female body size was derived from Nentwig et al. (2020) and Le Péru (2007) in five classes (class 1:>1 mm, class 2: 1-5 mm, class 3: 5-10 mm, class 4: $10-15 \mathrm{~mm}$, class 5: $>15 \mathrm{~mm}$ ). (ii) Four foraging strategies (hunting, run and kill, sit and wait, trap 
strategy). (iii) Five habitat hygrometry affinities (dry, very dry, very wet, wet, no preference). (iv) Four circadian activity rhythms (diurnal, crepuscular, nocturnal, no preference) were derived from the "Biological \& Ecological functional Traits of Soil Invertebrates" database (Hedde et al. 2012; BETSI 2020). (v) Ballooning or not (binary), which is the propensity to aerial dispersion of juveniles and adults, was taken from Bell et al. (2005). (vi) Kovoor and Muñoz-Cuevas (2000) detailed the vegetation strata affiliated to spider habitat preference: either on the vegetation or the ground ("Appendix 2").

\section{Data analysis}

\section{Environmental variables}

Differences in vegetation variables (vegetation percent cover and species richness) between years were tested separately for the two sites. We used Generalized Linear Mixed Models (GLMM), one for each variable and each site, with sampling year as a fixed effect and plots as a random effect, in order to take repeated measurements in the same plots over multiple years into account. These analyses were followed by pairwise comparisons with a Tukey adjustment. Models were fitted with a Poisson error distribution for species richness and a beta error distribution for the other variables. We used packages emmeans (Lenth et al. 2020), car (Fox and Weisberg 2020) and glmmTMB (Brooks et al. 2017).

To test the effects of environmental variables on spider abundances, we used the mvabund package (Wang et al. 2012) to create a Multivariate Abundance Data Object from the species abundance matrix. We fitted a multivariate linear model with environmental variable matrix as a fixed effect and a negative binomial distribution, followed by a test with the anova function, to make inferences about which environmental variables are associated with the multivariate abundances (Wang et al. 2012).

\section{Taxonomic diversity and species abundances}

Differences in spider taxonomic diversity [species richness, Simpson index 1/D, Shannon Evenness $\mathrm{e}^{\mathrm{H}}$ between years were tested separately for the two sites. We used GLMMs as described above with traps as a random factor and a Poisson error distribution. To test variations in spider species abundance between years, we used a Generalized Linear Model (GLM) for Multivariate Abundance Data from the mvabund package (Wang et al. 2012) with sampling year as a fixed effect, followed by a test with the anova function. These GLMs were fitted with a negative binomial distribution.

\section{Taxonomic composition and beta diversity}

Spider assemblage composition was analyzed using one non-metric multidimensional scaling (NMDS) analysis at each site. NMDSs were run on presence-absence data and based on Jaccard dissimilarities (package vegan: Oksanen et al. 2019). To run these NMDSs, we removed all species with less than one individual in our data set. We tested for dissimilarity in community composition between years with a PERMANOVA (pairwise distances calculated with pairwise adonis tests with Jaccard distances and 999 permutations). We then partitioned beta diversity between years into its two components: the turnover (replacement of some species by others between sampling events) and nestedness (loss or gain of 
species between sampling events) (package betapart: Baselga et al. 2018). We calculated these components using mean annual species abundances.

\section{Functional diversity}

Functional species richness (FRic) and functional evenness (FEve) were calculated using the function Distance-Based Functional Diversity Indices of FD package (Laliberté et al. 2014) and two matrices: a functional traits matrix and an abundance matrix of species with at least three individuals at each site. To find out if there were differences in FRic and FEve between years, we used a GLMM as described above with traps as a random effect with a Poisson error distribution for FRic and a beta error distribution for FEve.

\section{Trait response to environmental gradient}

In order to evaluate trait responses to environmental gradients, we analyzed simultaneously three matrices containing the following information: L (species abundance across samples), R (environmental characteristics of samples) and Q (species traits). We thus performed an RLQ analysis, which crosses traits and environmental variables weighted by species abundances, using the RLQ function of ade4 package (Dray et al. 2012).

All data analyses were conducted using the free software R-3.6.2 (R Development Core Team 2020).

\section{Results}

\section{Changes in environmental variables and their effects on spider abundances}

Most vegetation variables measured on the plant community at the matorral site did not differ significantly across years (e. g. total plant cover $\chi^{2}=0.001, \mathrm{p}=1.000$; shrub cover $\chi^{2}=8.53, \mathrm{p}=0.129$; plant species richness $\left.\chi^{2}=7.54, \mathrm{p}=0.184\right)$. Similarly, the percent cover of native shrubs and the total cover of herbaceous species in the Carpobrotus removal site did not vary significantly with time. However, total vegetation cover, Carpobrotus and litter cover were significantly higher before Carpobrotus control and dropped in 2013. Both total vegetation cover and litter cover had significantly increased by 2019 while Carpobrotus cover remained close to zero (Table 1). Bare ground cover first increased significantly in 2013 and then decreased (Table 1). Plant species richness significantly increased between before and after Carpobrotus removal from 10 to 23 species $/ 100 \mathrm{~m}^{2}$ plot (Table 1).

None of the vegetation variables had significant effects on spider mean abundances at the matorral site. The mean abundances of spiders at the Carpobrotus removal site increased significantly with increasing cover of herbaceous species $(F=140.69, p=0.002)$, litter $(\mathrm{F}=68.03, \mathrm{p}=0.002)$, shrubs $(\mathrm{F}=59.72, \mathrm{p}=0.016)$, while they decreased with increasing Carpobrotus cover $(\mathrm{F}=58.08, \mathrm{p}=0.030)$.

Autumn and spring rainfall averaged $725 \mathrm{~mm}$ over the 6 years of the study spread between 2010 and 2019. Rainfall in 2015 was $44 \%$ higher $(1045 \mathrm{~mm})$ than over the 6 years, and 45\% lower in 2017 (390 mm) (Table 2). Rainfall during sampling (mid-April through to June) averaged $91 \mathrm{~mm}$. It was high in 2010 (245 $\mathrm{mm})$, nearly the average in 2013 and 2015, and very low in the 3 other years (Table 2). 
Table 1 Environmental variables (mean values $\pm \mathrm{SE}$ ) of the plant community in the area invaded by Carpobrotus sp. before removal $(2010,2011)$ and after removal (2013 to 2019)

\begin{tabular}{|c|c|c|c|c|c|c|c|c|}
\hline & 2010 & 2011 & 2013 & 2015 & 2017 & 2019 & $\chi^{2}$ & $\mathrm{P}$ \\
\hline$\%$ cover vegetation & $87.5 \pm 0^{b}$ & $87.5 \pm 0^{b}$ & $45.8 \pm 14.4^{\mathrm{a}}$ & $70.8 \pm 28.8^{a b}$ & $87.5 \pm 0^{b}$ & $\begin{array}{l}79.2^{ \pm} \\
14.4^{\mathrm{b}}\end{array}$ & 39.8 & $* * *$ \\
\hline$\%$ cover shrubs & $13.6 \pm 6.9$ & $9.6 \pm 6.9$ & $7.8 \pm 8.9$ & $7.8 \pm 8.9$ & $7.8 \pm 8.9$ & $3.8 \pm 3.2$ & 10.08 & n.s. \\
\hline $\begin{array}{l}\% \text { cover herbs / grasses } \\
\text { (including Carpobrotus) }\end{array}$ & $87.5 \pm 0^{\mathrm{a}}$ & $87.5 \pm 0^{\mathrm{a}}$ & $45.8 \pm 14.4^{\mathrm{a}}$ & $79.2 \pm 14.4^{\mathrm{a}}$ & $60.2 \pm 47.3^{a}$ & $\begin{array}{l}79.2 \pm \\
14.4^{\mathrm{a}}\end{array}$ & 14.63 & $\begin{array}{l}* \text { (post-hoc } \\
\text { n.s.) }\end{array}$ \\
\hline$\%$ cover Carpobrotus & $79.3 \pm 14.4^{b}$ & $79.3 \pm 14.4^{b}$ & $5.6 \pm 0.0^{\mathrm{a}}$ & $3.9 \pm 2.9^{\mathrm{a}}$ & $2.1 \pm 3.0^{\mathrm{a}}$ & $5.6 \pm 0.0^{\mathrm{a}}$ & 450.21 & $* * *$ \\
\hline$\%$ cover bare soil & $0.1 \pm 0^{\mathrm{a}}$ & $1.9 \pm 3.2^{\mathrm{a}}$ & $39.3 \pm 22.5^{c}$ & $13.6 \pm 6.9^{b}$ & $5.6 \pm 0.0^{\mathrm{ab}}$ & ${ }_{b} 13.6 \pm 6.9$ & 75.92 & $* * *$ \\
\hline$\%$ cover litter & $87.5 \pm 0^{c}$ & $87.5 \pm 0^{c}$ & $20.2 \pm 16.2^{a b}$ & $5.5 \pm 0.0^{\mathrm{a}}$ & $9.5 \pm 6.9^{\mathrm{a}}$ & $\begin{array}{l}30.8 \pm \\
11.5^{b}\end{array}$ & 188.86 & $* * *$ \\
\hline \# of plant species & $12.0 \pm 2.6^{\mathrm{a}}$ & $11.3 \pm 4.6^{\mathrm{a}}$ & $21.7 \pm 4.0^{b}$ & $23.0 \pm 4.0^{b}$ & $22.0 \pm 2.6^{b}$ & $23.0 \pm 2.6$ & 23.93 & $* * *$ \\
\hline
\end{tabular}

Differences among years were tested with a GLMM with plots as a random factor to consider temporal correlation (\% cover were analyzed with a beta distribution and species richness with a Poisson distribution). Between years effects were tested using a Tukey post-hoc test. Different letters indicate significant differences between treatments $(\mathrm{P}<0.05)$. n.s. not significant. Environmental variables were stable for the plant community in the control area. Shading highlights greater values

Table 2 Summary of the main weather data (Porquerolles weather station)

\begin{tabular}{llllllll} 
& 2010 & 2011 & 2013 & 2015 & 2017 & 2019 & $\begin{array}{l}\text { Mean over } \\
\text { the } 6 \text { years }\end{array}$ \\
\hline $\begin{array}{l}\text { Autumn \& winter rainfall (mm) } \\
\text { from Sept to April }\end{array}$ & 846.9 & 657 & 811.4 & 1044.7 & 390.4 & 598.6 & 724.8 \\
\hline $\begin{array}{l}\text { Rainfall }(\mathrm{mm}) \text { during sampling } \\
\text { mid-April to end of June }\end{array}$ & 244.9 & 26.2 & 107.7 & 149.8 & 13.1 & 3.3 & 90.8 \\
\hline $\begin{array}{l}\text { Mean of average temperatures } \\
\text { Sept to April }\left({ }^{\circ} \mathrm{C}\right)\end{array}$ & 12.1 & 11.5 & 11.9 & 12.7 & 12.5 & 12.7 & 12.3 \\
\hline $\begin{array}{l}\text { Mean of average temperatures } \\
\text { during sampling mid-April to end } \\
\text { of June }\left({ }^{\circ} \mathrm{C}\right)\end{array}$ & 17.1 & 19.8 & 17.6 & 19.7 & 19 & 19.5 & 18.8 \\
\hline
\end{tabular}

Rainfall and temperatures are given for (i) the autumn and winter preceding each sampling (September to April) and (ii) the sampling period (mid-April to end of June) precisely calculated for each year

Temperature before sampling (September to April) was lower the first 3 years $\left(11.8^{\circ} \mathrm{C}\right)$ then higher the last 3 years $\left(12.6^{\circ} \mathrm{C}\right)$ compared to the mean over the 6 years of the study (2010-2019: $12.3{ }^{\circ} \mathrm{C}$ ) (Table 2), and it had significant positive effects on spider mean abundances at the restoration site $(\mathrm{F}=72.69, \mathrm{p}=0.003)$. Temperature during sampling was lower than the long-term mean $\left(18.8^{\circ} \mathrm{C}\right)$ in $2010\left(17.1^{\circ} \mathrm{C}\right)$ and $2013\left(17.6^{\circ} \mathrm{C}\right)$ then above the other years (Table 2 ), and it had significant positive effects on spider mean abundances at the matorral site $(\mathrm{F}=69.96, \mathrm{p}=0.014)$.

\section{Spider diversity and variations in spider abundances}

In total, we captured 1814 adult spider specimens in our plots, distributed in 51 taxa, none of which were exotic ("Appendix 1"). Higher abundance but lower richness was found at the Carpobrotus removal site $(\mathrm{N}=1066,34$ taxa), than at the matorral site $(\mathrm{N}=748,41$ taxa). At the Carpobrotus removal site, the most frequent species were Oecobius navus (53.9\%) and Dysdera erythrina (15.3\%) before restoration, and Aelurillus v-insignitus (24.0\%) Nomisia celerrima (14.7\%) and Xysticus spp. (10.4\%) after restoration. At the 
matorral site, the most frequent species were O. navus (29.4\%), A.v-insignitus (12.3\%), Zodarion timidum (12.3\%) and D. erythrina (10.8\%).

At the Carpobrotus removal site, species richness, Simpson diversity index (1/D) and Shannon Evenness $\left(\mathrm{e}^{\mathrm{H}}\right)$ significantly increased after Carpobrotus removal, with the two first years (2010-2011) being different from the two last years $(2017-2019)\left(\chi^{2}=66.9\right.$, $\mathrm{p}<0.001, \chi^{2}=23.7, \mathrm{p}<0.001, \chi^{2}=44.2, \mathrm{p}<0.001$ respectively; Fig. 1). At the matorral site, there were no significant differences between years in terms of species richness $\left(\chi^{2}=8.2, p=0.14\right)$, Simpson diversity index $(1 / D)\left(\chi^{2}=0.4, p=0.99\right)$ or Shannon Evenness $\left(\mathrm{e}^{\mathrm{H}}\right)\left(\chi^{2}=2.9, \mathrm{p}=0.72\right)$ (Fig. 1).

Abundances of spiders significantly differed between years at the Carpobrotus removal site $(\mathrm{LRT}=436.2, \mathrm{p}=0.001)$ : O. navus abundance decreased after restoration $(\mathrm{LRT}=52.31, \mathrm{p}=0.001)$ and increased for Cepheia longiseta $(\mathrm{LRT}=32.24, \mathrm{p}=0.001)$, Nomisia celerrima (LRT $=34.36, \mathrm{p}=0.003)$, A. v-insignitus $(\mathrm{LRT}=29.38, \mathrm{p}=0.007)$, Zodarion elegans $(\mathrm{LRT}=26.65, \mathrm{p}=0.018)$ and Linyphiidae spp. $(\mathrm{LRT}=24.39, \mathrm{p}=0.027)$. Xysticus sp. were more abundant in 2015 and 2017 (LRT=37.82, p=0.002). Abundances of spiders differed significantly between years at the matorral site (LRT $=277.60$, $\mathrm{P}=0.001)$ : Lyniphiidae spp. (LRT $=28.12, \mathrm{p}=0.002)$ were more abundant in 2013, 2017 and 2019, and D. erythrina $(22.92, \mathrm{p}=0.005)$ in 2010 and 2015.

\section{Assemblage composition}

At the Carpobrotus removal site, the NMDS ordination clearly separated the years before $(2010,2011)$ and after restoration $(2015,2017,2019)$, with the first post-removal year (2013) being intermediate (stress: 0.18; permanova $p=0.001$; Fig. 2a). The last two years of sampling (2017 and 2019) also appear different from each other (Fig. 2a). The years before restoration are associated with species, such as Atypus affinis, Hogna radiata, Heliophanus kochii, O. navus, Scytodes thoracica, Euophrys spp. and Dictynidae. The years after restoration are associated with species, such as A. v-insignitus, Arctosa villica, $C$. longiseta, Evarcha jucunda, Filistata insidiatrix, Nemesia congener, Nurscia albomaculata, Pulchellodromus pulchellus, Saitis barbipes. Compositional variations in spider assemblages were better explained by species turnover between years (range 12.3 to $77.3 \%$ ) than by the nestedness component of beta diversity (range 0.4 to $24.9 \%$ ) (Table 3). Differences in turnover were greatest between pre- and post-Carpobrotus removal (range 45.2 to $77.3 \%$ ) (Table 3).

NMDS ordination at the matorral site revealed the similarity of spider assemblages across years (stress: 0.16 ; permanova $\mathrm{p}=0.009$ but no significant differences between years; Fig. 2b). Compositional variations in spider assemblages were better explained by species turnover between years (range 19.7 to $41.7 \%$ ) than by the nestedness component of beta diversity (range 0.8 to $21.6 \%$ ) (Table 3 ).

\section{Assemblage functional diversity}

At the Carpobrotus removal site, functional richness (FRic) was significantly lower the 2 years before Carpobrotus removal and increased gradually over time $\left(\chi^{2}=29.57\right.$, $\mathrm{p}<0.001$, Fig. 3), with functional evenness tending to be lower before Carpobrotus removal $\left(\chi^{2}=0.95, \mathrm{p}=0.052\right)$. At the matorral site, there were no significant differences in functional richness nor evenness between years $\left(\chi^{2}=1.72, p=0.880\right.$ and $\chi^{2}=3.66$, $\mathrm{p}=0.590$, respectively). 

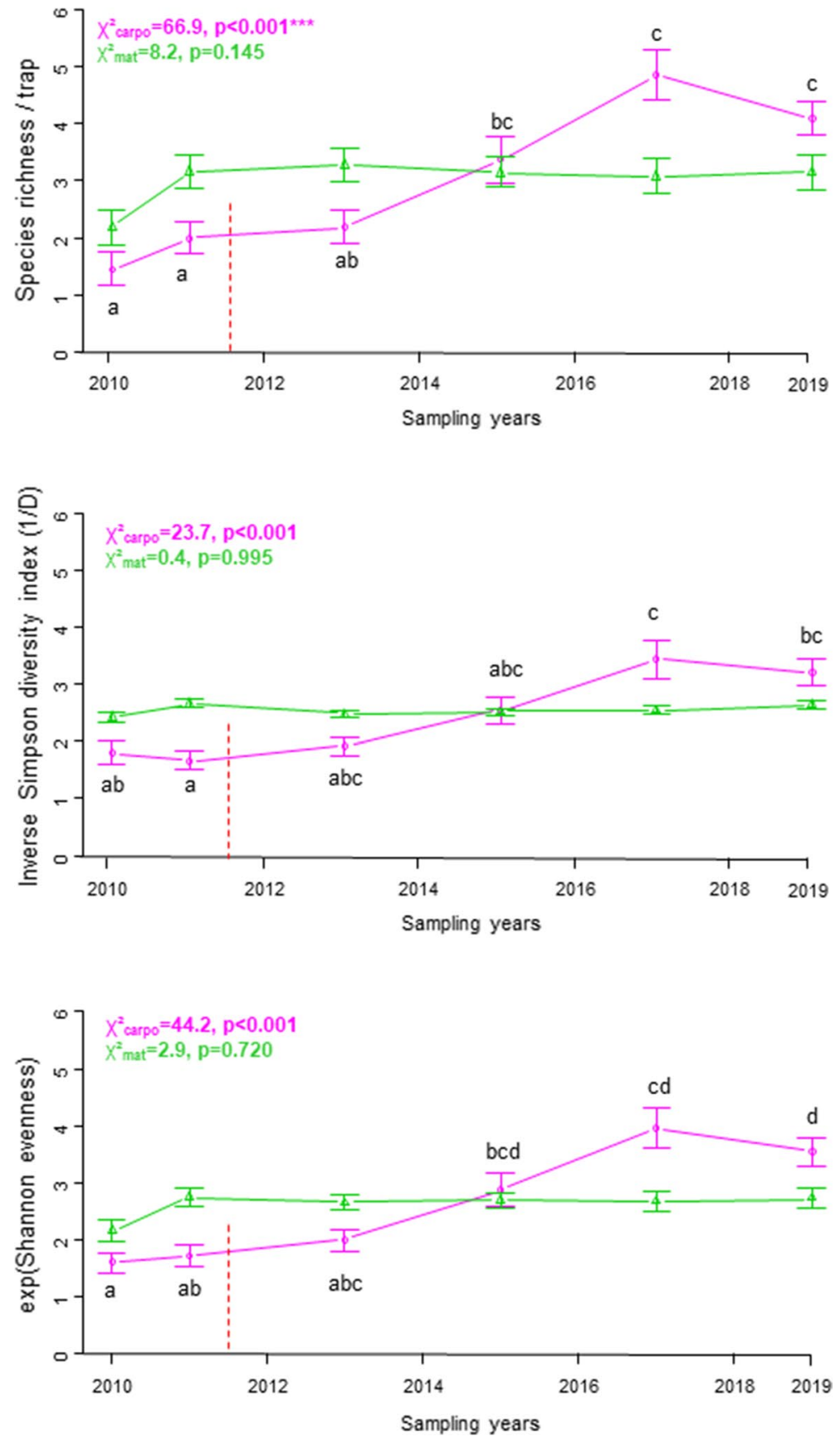

Fig. 1 Annual spider species richness (S) and species diversity (Simpson diversity index 1-D and Shannon evenness $\mathrm{e}^{\mathrm{H}}$ (mean values $+\mathrm{SE}$ ) for the Carpobrotus removal site (pink diamonds) and the matorral site (green triangles). The red dotted line represents the Carpobrotus removal period (winter 2011-2012). We used GLMM, one for each variable and each site, with years as a fixed factor and plots as a random factor, followed by Tukey test when significant. Models were fitted with a Poisson family. Bars not sharing letters were significantly different between years $(\mathrm{p}<0.05)$ 
Fig. 2 a NMDS ordination of spiders assemblage on presence/absence data at the Carpobrotus removal site (stress $=0.18$, Permanova: $\mathrm{p}=0.001^{* * *}$ ). 2010 and 2011 (pre-control years), colored in red, were significantly different from the post-control years (in green). Year entries represent the centroids for each sampling year, and the polygons surround the points corresponding to each sampling year. b NMDS ordination of spiders assemblage on presence/absence data at the control site (stress $=0.16$, Permanova: $p=0.009$; but no significant differences between years - see table above). Year entries represent the centroids for each sampling year, and the polygons surround the points corresponding to each sampling year

\section{Trait response to environmental gradient}

At the Carpobrotus removal site, the RLQ analysis (projected inertia (\%): Axis $1=78.63$, Axis $2=8.26$, Fig. 4) separated the sites in two groups on the first axis: the pre-removal years 2010-2011, and the post-removal years 2013-2019. Pre-removal years were characterized by: high cover of litter and Carpobrotus, hygrophilous spiders such as D. erythrina and Amaurobius erberi, nocturnal and medium-size species with hunting or run and kill strategies. Year 2013 was characterized by a high cover of bare ground and a low plant species richness, with Linyphiidae species. Years 2015-2019 were characterized by: high plant richness and temperature before sampling, xerophilous spiders such as Z. elegans, A. $v$-insignitus and Zelotes tenuis, diurnal species with trap or sit and wait foraging strategies.

At the matorral site, the RLQ analysis (inertia: $\mathrm{A} \times 1=63.2, \mathrm{~A} \times 2=18.8$ ) did not discriminate the years clearly.

\section{Discussion}

While rainfall was highly variable between years, which is typical of Mediterranean climates (Deitch et al. 2017), vegetation (species richness and percent cover of vegetation, native shrubs, native herbaceous species) and percent cover of litter and bare ground remained relatively stable at the matorral site. This is consistent with other shrublands under normal Mediterranean climatic variation (Rodriguez-Ramirez et al. 2017).

Spider alpha-diversity (spider richness, taxonomic and functional diversities) and assemblage composition also remained stable at the matorral site during the study. Spider assemblages can vary with habitat condition, vegetation structure and succession stages (Bonte et al. 2002): stable habitats without disturbance, such as shrublands, have more stable assemblages over time. As there was no Carpobrotus at this site and no disturbance or management, this relative stability in the face of climate variation was not surprising, given the stability of the vegetation. Woodlice variations are dependent on rainfall during sampling and could explain the variations in D. erythrina which feed mainly on these prey species (Cooke 1965). Considering the great taxonomic and ecological diversity within Linyphiidae (Draney 1997), the data analysis at the family level may hide possible interannual variations in the composition of Linyphiid assemblages that could be revealed by a lower taxonomic level study. Overall, this site did not undergo major changes in spider assemblages, and demonstrate their relative stability even with inter-annual climatic variations.

Vegetation and environmental parameters changed dramatically at the Carpobrotus removal site as a result of Carpobrotus removal. Carpobrotus cover was 75\% lower in 2013 due to the removal of Carpobrotus in 2011-2012 and bare ground was nearly $40 \%$ higher. Open habitats containing a lot of bare ground are generally characterized by relatively species-poor spider communities where small r-selected Linyphiidae spp. and Synaphridae, 


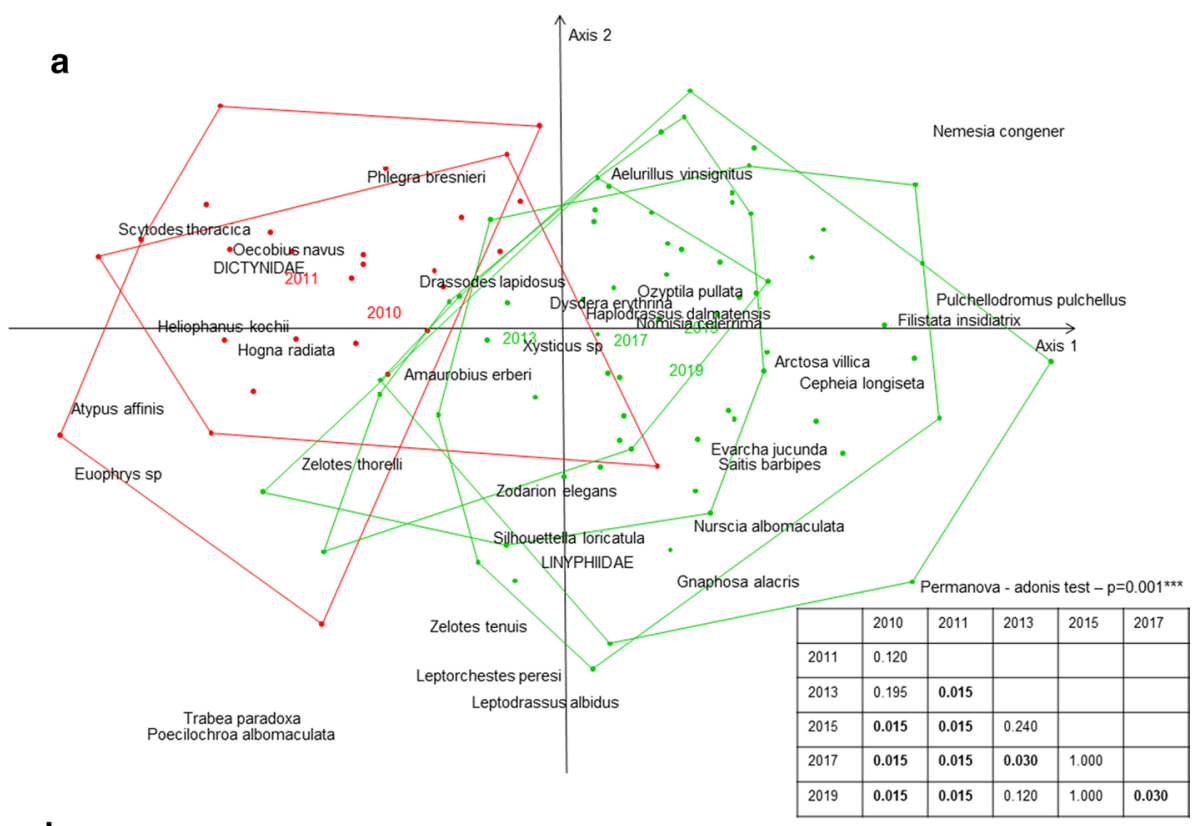

b

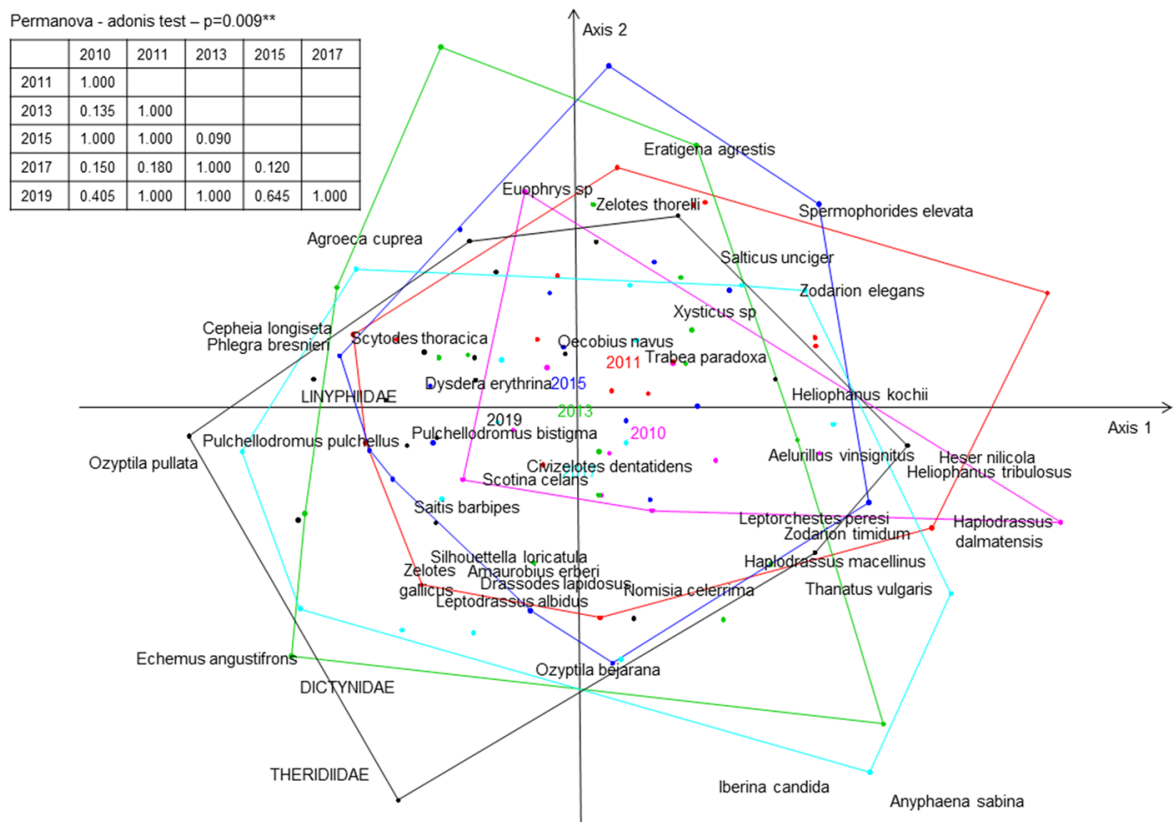

such as C. longiseta, can dominate (Bell et al. 2001; Buchholz 2010; Negro et al. 2013), as they build their webs over depressions in the soil and are known to be good aerial dispersers (Alderweireldt 1994). The opening up of the environment facilitates spider mobility 
Table 3 Taxonomic turnover (replacement of some species by others between 2 years) and taxonomic nestedness (loss or gain of species between 2 years) - resultant components of taxonomic diversity on abundance data (a) at the Carpobrotus removal site (b) at the matorral site. Turnover is shown in dark grey and nestedness in light grey

\begin{tabular}{|c|c|c|c|c|c|c|c|c|c|c|c|c|c|}
\hline \multirow[t]{2}{*}{ (a) } & & \multicolumn{5}{|c|}{ Nestedness } & \multicolumn{2}{|c|}{ (b) } & \multicolumn{5}{|c|}{ Nestedness } \\
\hline & & 2010 & 2011 & 2013 & 2015 & 2017 & 2019 & 2010 & 2011 & 2013 & 2015 & 2017 & 2019 \\
\hline & 2010 & & 11.2 & 5.8 & 12.7 & 24.9 & 8.9 & & 8.5 & 21.6 & 12.6 & 12.7 & 9.9 \\
\hline \multirow{5}{*}{$\begin{array}{l}\overrightarrow{0} \\
\stackrel{0}{0} \\
\stackrel{\Xi}{\Xi} \\
.\end{array}$} & 2011 & 48.2 & & 4.4 & 0.4 & 63 & 0.5 & 36 & & & 3.8 & 3.6 & 3 \\
\hline & 2013 & 51.1 & 56.3 & & 7 & 20 & 4.6 & 26.3 & 25.5 & & 8.6 & 8.5 & 9.8 \\
\hline & 2015 & 45.2 & 73.9 & 39.4 & & 22.1 & 2.1 & 29.3 & 19.7 & 36.4 & & 0.8 & 0.3 \\
\hline & 2017 & 45.7 & 76.6 & 44.4 & 12.3 & & 21 & 33.5 & 41.7 & 29.9 & 42.8 & & 1.2 \\
\hline & 2019 & 54.7 & 77.3 & 43.4 & 40.1 & 26.8 & & 43.1 & 29 & 29.8 & 34.4 & 34.2 & \\
\hline
\end{tabular}
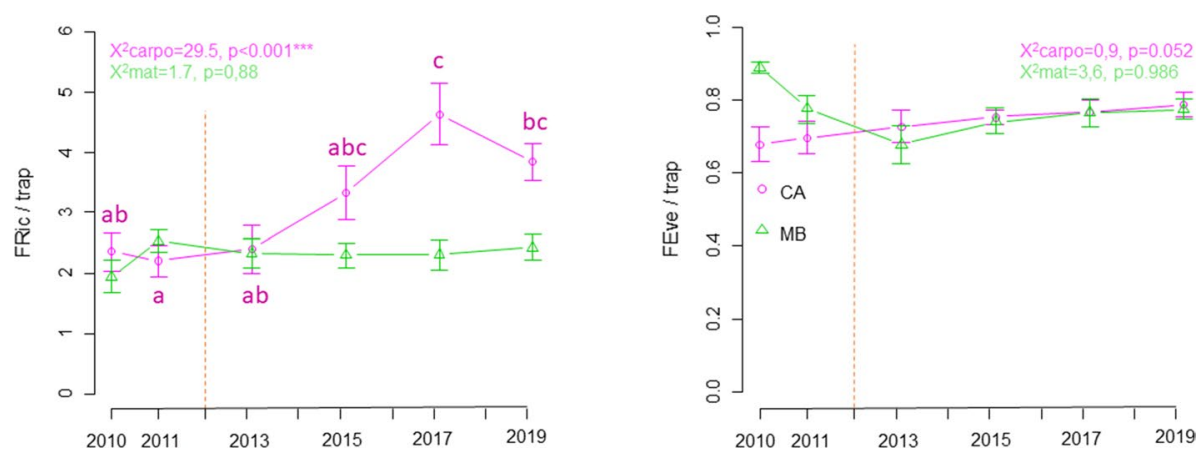

Fig. 3 Annual spider species functional richness (FRic $\pm \mathrm{SE}$ ) and evenness (FEve $\pm \mathrm{SE})$ for the Carpobrotus removal site (pink diamonds) and the matorral site (green triangles). The red dotted line represents the Carpobrotus removal period (winter 2011-2012). We used GLMM fitted with a Poisson family for FRic and fitted with a beta family for FEve, year as a fixed factor and plot as random factors, followed by pairwise contrast comparisons with a Tukey adjustment. Bars not sharing letters were significantly different between years $(\mathrm{p}<0.05)$

on the soil, as well as their catchability in pitfalls (Woodcock 2005; Brown and Matthews 2016). Temperature is also known to have potential effects on pitfall catches of epigeal arthropods (Saska et al. 2013).

Native vegetation, mainly herbaceous species, recolonized the site after Carpobrotus removal, doubling plant species richness (Buisson et al. 2020). The landscape therefore changed greatly from a dense mat of Carpobrotus to a diverse halophilous grassland with some chamaephytes, such as Jacobaea maritima ssp. maritima, Lotus creticus ssp. cytisoides, Euphorbia pithyusa, Sonchus bulbosus and Bromus diandrus ssp. diandrus. The vegetation was not only rich in species, but also in structure, providing various plant heights and microhabitats (less litter, but more diversified litter and more bare ground). Spider assemblages are known to vary with vegetation composition (Schaffers et al. 2008) and structure (Uetz 1991; Bell et al. 2001), that could explain the increase in spider species richness, the change in species composition and the high turnover of species between pre- and post-control years. With increasing vegetation cover, the habitat becomes more attractive for foliage-dwelling spiders and as a consequence, species richness increases 


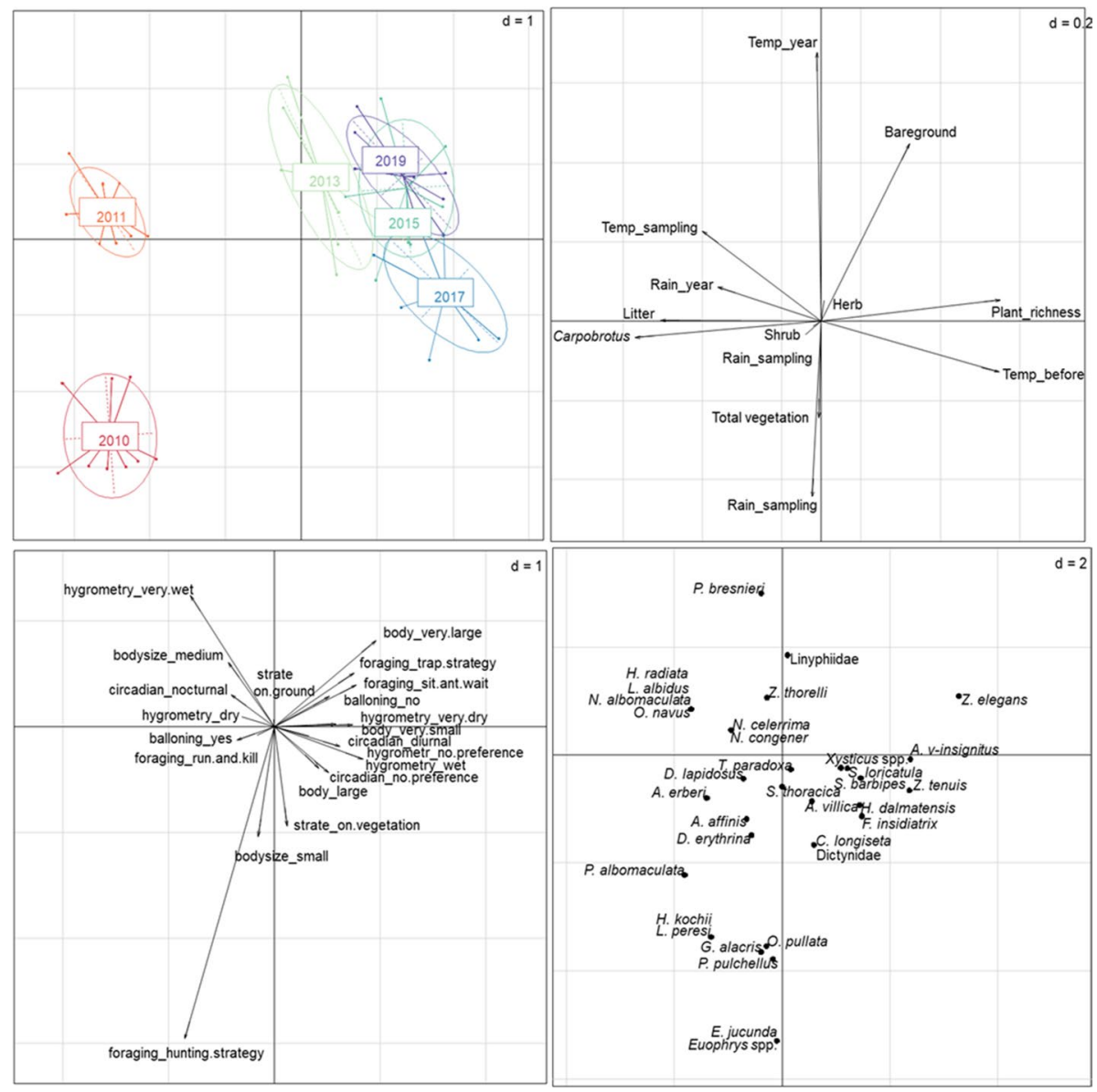

Fig. 4 RLQ analysis of spider species at the Carpobrotus removal site (projected inertia: Axis $1=78.63 \%$, Axis $2=8.26 \%$ ). The statistic measures the link between three tables: L (species abundance with more than three occurrences across samples, "Appendix 1"), R (environmental variables of samples, Tables 1 and 2) and Q (species traits on adult, "Appendix 2")

(Bell et al. 2001). Similar rapid changes in spider assemblages after invasive plant removal was also observed by Eckert et al. (2019) and Gratton and Denno (2005) only 6 years after the removal of invasive Pinus spp. and Phragmites australis respectively.

The species abundance most significantly affected by Carpobrotus removal was $O$. navus, a tiny cosmopolitan spider living in a tent-like web (Líznarová et al. 2013) that is frequently associated with litter (Nentwig et al. 2020). Its steady decline after Carpobrotus removal may have been caused by the marked decrease in Carpobrotus litter after 2013 that was slowly replaced by native herbaceous species' litter which is decomposable and less persistent than Carpobrotus litter. Variation in litter habitats have long been known to affect litter-dwelling spider species richness and composition, moreover, litter complexity appears to be the most influential variable in summer (Uetz 1979). Indeed, Carpobrotus forms litter that is present throughout the year while in the restored habitat, annual plants die and some perennial plants dry out in summer, making 
the litter habitat more variable and perhaps less suitable for O. navus. O. navus may also have been partly replaced by a species with similar traits, C. longiseta. Other studies have reported negative indirect effects of invasive species eradication on native species (Zavaleta et al. 2001; Bergstrom et al. 2009; Skurski et al. 2014) and further investigation of species interactions, or more detailed species traits, might help understanding why one decreases while another increases.

On the other hand, Carpobrotus removal benefited spiders with ambush or trap strategies that forage primarily on vegetation, such as Aelurillus v-insignatus and Xysticus spp. (Jiménez-Valverde and Lobo 2007). Smith DiCarlo and DeBano 2019) have recently shown that Xysticus spp. are favored by increasing invasive plant litter cover, but the litter was produced by annual grass species such as Bromus tectorum in that study, very close to the native $B$. diandrus ssp. diandrus found on Bagaud Island after Carpobrotus removal. They may also take advantage of the richer vegetation structure, thus increasing the range of ambush possibilities on plants. As ground-dwelling hunters, A. villica, $N$. celerrima and $Z$. elegans depend on vegetation with patches of bare ground (Warui et al. 2005) that facilitate the running on the ground and the capture of prey. Ants, which exclusively constitute the diet of Z. timidum (Cushing 2012), increased significantly after restoration in our study (unpublished data). These three taxa, A. v-insignitus, A. villica, N. celerrima and Z. elegans, are also characterized by their affinity with dry and sunny environments (Roberts 2014).

This project followed the removal of a quasi-monodominant Carpobrotus mat that created a relatively moist environment with a thick very slowly decomposable litter. The environment was recolonized by grassland vegetation with a mix of annual and perennial herbaceous plants as well as small chamaephytes. This created a structurally diverse habitat in space and time, leading to an increase in the diversity of spider assemblages. Although the study site was located on an island, the size of the Carpobrotus patch was only $0.5 \mathrm{ha}$, compared to the size of the island (59 ha). The site was surrounded with native vegetation from where spiders could recolonize either on the ground or by ballooning. Future studies should be carried out in areas with larger Carpobrotus patches to determine whether recolonization can be as efficient as was observed in this study. These studies also need to be carried out on other islands and coastal areas of the Mediterranean to test the replicability of our results in other environments.

Acknowledgements We thank all the volunteers for valuable support with the fieldwork and the National Park of Port-Cros for the helpful assistance during the whole study, the students and the technical staff for their contribution in sorting invertebrates to the taxonomic order. We thank Kevin Cilleros for his expertise in functional biodiversity analysis, Kurt Villsen for reviewing the English, Truman P. Young and two anonymous referees who made valuable comments on the manuscript. The restoration and research projects were supported by the European Regional Development Fund, French South Region Council, National Park of Port-Cros, Naturalia-Environnement, Conservatoire de 1'Espace Littoral et des Rivages Lacustres and Fondation Total. EB was supported by the France-Berkeley Fund.

Author contributions PP conceived and designed the research; JB, EB, OH performed sampling and sorted invertebrates; JB, OH, CM, PO identified spiders; JB, OH, EB analyzed the data; JB, EB wrote the paper; all authors edited the manuscript. All the authors read and approved the final version of the manuscript.

Funding The restoration and research projects were supported by European Regional Development Fund, Fondation Total, Conservatoire de l'Espace Littoral et des Rivages Lacustres, Conseil Régional ProvenceAlpes-Côte d'Azur, Naturalia-Environnement, National Park of Port-Cros and France-Berkeley Fund.

Data availability Available upon request. 
Ethical approval Invertebrates sampling was approved by the scientific board of the National Park of PortCros.

\section{Appendices}

\section{Appendix 1}

Species list and abundances by site. Both sites were sampled equally. Due to difficulties in taxonomic identification, the following species were pooled: Altella lucida and Lathys stigmatisata under the family Dictynidae; Agyneta pseudorurestris, Agyneta rurestris, Cnephalocotes sp., Microctenonyx subitaneus, Tenuiphantes herbicola, Theonina cornix and Typhochrestus bogarti under the family Linyphiidae; Crustulina scabripes, Enoplognatha mandibularis and Lasaeola testaceomarginata under the family Theridiidae; Euophrys gambosa, Euophrys nigripalpis and Euophrys rufibarbipes under the genus Euophrys; Xysticus kochii and Bassaniodes bufo (before Xysticus bufo) under the genus Xysticus.

\begin{tabular}{lrrrc}
\hline & $\begin{array}{l}\text { Carpobrotus } \\
\text { removal }\end{array}$ & Matorral site & Sum & $\begin{array}{l}\text { Relative } \\
\text { abundance } \\
(\%)\end{array}$ \\
\hline Oecobius navus & 255 & 220 & 475 & 26.19 \\
Aelurillus vinsignitus & 190 & 92 & 282 & 15.55 \\
Dysdera erythrina & 95 & 81 & 176 & 9.70 \\
Nomisia celerrima & 113 & 8 & 121 & 6.67 \\
Linyphiidae & 51 & 51 & 102 & 5.62 \\
Zodarion timidum & 0 & 92 & 92 & 5.07 \\
Drassodes lapidosus & 77 & 14 & 91 & 5.02 \\
Xysticus spp. & 82 & 1 & 83 & 4.58 \\
Euophrys spp. & 16 & 30 & 46 & 2.54 \\
Zelotes thorelli & 15 & 27 & 42 & 2.32 \\
Cepheia longiseta & 1 & 40 & 2.21 \\
Scytodes thoracica & 39 & 21 & 38 & 2.09 \\
Zodarion elegans & 17 & 6 & 36 & 1.98 \\
Saitis barbipes & 30 & 24 & 25 & 1.38 \\
Nurscia albomaculata & 1 & 0 & 17 & 0.94 \\
Arctosa villica & 17 & 0 & 15 & 0.83 \\
Silhouettella loricatula & 15 & 2 & 9 & 0.72 \\
Amaurobius erberi & 11 & 7 & 9 & 0.50 \\
Scotina celans & 2 & 9 & 8 & 0.50 \\
Haplodrassus dalmatensis & 0 & 3 & 6 & 0.44 \\
Pulchellodromus pulchellus & 6 & 5 & 5 & 0.33 \\
Zelotes gallicus & 3 & & & 0.33 \\
Agroeca cuprea & 0 & 2 & 9.28 \\
\hline
\end{tabular}




\begin{tabular}{|c|c|c|c|c|}
\hline & $\begin{array}{l}\text { Carpobrotus } \\
\text { removal }\end{array}$ & Matorral site & Sum & $\begin{array}{l}\text { Relative } \\
\text { abundance } \\
(\%)\end{array}$ \\
\hline Hahnia candida & 0 & 5 & 5 & 0.28 \\
\hline Hogna radiata & 5 & 0 & 5 & 0.28 \\
\hline Leptodrassus albidus & 4 & 1 & 5 & 0.28 \\
\hline Phlegra bresnieri & 4 & 1 & 5 & 0.28 \\
\hline Pulchellodromus bistigma & 0 & 5 & 5 & 0.28 \\
\hline Spermophorides elevata & 0 & 5 & 5 & 0.28 \\
\hline Dictynidae & 3 & 1 & 4 & 0.22 \\
\hline Heliophanus kochii & 2 & 2 & 4 & 0.22 \\
\hline Leptorchestes peresi & 1 & 3 & 4 & 0.22 \\
\hline Eratigena agrestis & 0 & 3 & 3 & 0.17 \\
\hline Haplodrassus macellinus & 0 & 3 & 3 & 0.17 \\
\hline Ozyptila pullata & 2 & 1 & 3 & 0.17 \\
\hline Thanatus vulgaris & 0 & 3 & 3 & 0.17 \\
\hline Theridiidae & 0 & 3 & 3 & 0.17 \\
\hline Atypus affinis & 2 & 0 & 2 & 0.11 \\
\hline Civizelotes dentatidens & 0 & 2 & 2 & 0.11 \\
\hline Gnaphosa alacris & 2 & 0 & 2 & 0.11 \\
\hline Heliophanus tribulosus & 0 & 2 & 2 & 0.11 \\
\hline Heser nilicola & 0 & 2 & 2 & 0.11 \\
\hline Trabea paradoxa & 1 & 1 & 2 & 0.11 \\
\hline Anyphaena sabina & 0 & 1 & 1 & 0.06 \\
\hline Echemus angustifrons & 0 & 1 & 1 & 0.06 \\
\hline Evarcha jucunda & 1 & 0 & 1 & 0.06 \\
\hline Filistata insidiatrix & 1 & 0 & 1 & 0.06 \\
\hline Nemesia congener & 1 & 0 & 1 & 0.06 \\
\hline Ozyptila bejarana & 0 & 1 & 1 & 0.06 \\
\hline Poecilochroa albomaculata & 1 & 0 & 1 & 0.06 \\
\hline Zelotes tenuis & 1 & 0 & 1 & 0.06 \\
\hline No. individuals & 1066 & 748 & 1814 & 100.00 \\
\hline No. species & 34 & 41 & 51 & \\
\hline
\end{tabular}

\section{Appendix 2: Functional traits matrix.}

\begin{tabular}{lllllll}
\hline Taxa & Size class & Foraging & Strate & Hygrometry & $\begin{array}{l}\text { Circadian } \\
\text { activity }\end{array}$ & Ballooning \\
\hline $\begin{array}{c}\text { Aelurillus } \\
\text { vinsignitus }\end{array}$ & Medium & $\begin{array}{c}\text { Hunting } \\
\text { strategy } \\
\text { Run and kill }\end{array}$ & On vegetation & Dry & Diurnal & Yes \\
$\begin{array}{l}\text { Agroeca } \\
\text { cuprea }\end{array}$ & Small & No preference & Nocturnal & Yes \\
\hline
\end{tabular}




\begin{tabular}{|c|c|c|c|c|c|c|}
\hline Taxa & Size class & Foraging & Strate & Hygrometry & $\begin{array}{l}\text { Circadian } \\
\text { activity }\end{array}$ & Ballooning \\
\hline $\begin{array}{l}\text { Amaurobius } \\
\text { erberi }\end{array}$ & Medium & Trap strategy & On ground & Very wet & Nocturnal & Yes \\
\hline $\begin{array}{l}\text { Anyphaena } \\
\text { sabina }\end{array}$ & Medium & Run and kill & On vegetation & No preference & Crepuscular & Yes \\
\hline Arctosa villica & Large & Run and kill & On ground & Dry & Diurnal & Yes \\
\hline Atypus affinis & Large & Trap strategy & On ground & Dry & No preference & No \\
\hline $\begin{array}{l}\text { Cepheia longi- } \\
\text { seta }\end{array}$ & Very small & Trap strategy & On ground & No preference & No preference & Yes \\
\hline $\begin{array}{l}\text { Civizelotes } \\
\text { dentatidens }\end{array}$ & Small & Run and kill & On ground & Dry & Nocturnal & No \\
\hline Dictynidae & Small & Trap strategy & On ground & Very dry & No preference & No \\
\hline $\begin{array}{l}\text { Drassodes } \\
\text { lapidosus }\end{array}$ & Large & Run and kill & On ground & Very dry & Nocturnal & Yes \\
\hline $\begin{array}{l}\text { Dysdera eryth- } \\
\text { rina }\end{array}$ & Large & Run and kill & On ground & Wet & Nocturnal & Yes \\
\hline $\begin{array}{l}\text { Echemus } \\
\quad \text { angustifrons }\end{array}$ & Medium & Run and kill & On ground & Dry & Nocturnal & Yes \\
\hline $\begin{array}{l}\text { Eratigena } \\
\text { agrestis }\end{array}$ & Large & Trap strategy & On ground & Dry & Nocturnal & Yes \\
\hline Euophrys spp. & Small & $\begin{array}{l}\text { Hunting } \\
\text { strategy }\end{array}$ & On vegetation & No preference & Diurnal & Yes \\
\hline $\begin{array}{l}\text { Evarcha } \\
\text { jucunda }\end{array}$ & Medium & $\begin{array}{l}\text { Hunting } \\
\text { strategy }\end{array}$ & On vegetation & Wet & Diurnal & Yes \\
\hline $\begin{array}{l}\text { Filistata insidi- } \\
\quad \text { atrix }\end{array}$ & Large & Trap strategy & On ground & Wet & No preference & Yes \\
\hline $\begin{array}{l}\text { Gnaphosa } \\
\text { alacris }\end{array}$ & Medium & Run and kill & On ground & Dry & Nocturnal & Yes \\
\hline $\begin{array}{r}\text { Haplodrassus } \\
\text { dalmatensis }\end{array}$ & Medium & Run and kill & On ground & Dry & Nocturnal & Yes \\
\hline $\begin{array}{l}\text { Haplodrassus } \\
\text { macellinus }\end{array}$ & Large & Run and kill & On ground & Dry & Nocturnal & Yes \\
\hline $\begin{array}{l}\text { Heliophanus } \\
\text { kochii }\end{array}$ & Small & $\begin{array}{l}\text { Hunting } \\
\text { strategy }\end{array}$ & On vegetation & No preference & Diurnal & No \\
\hline $\begin{array}{l}\text { Heliophanus } \\
\text { tribulosus }\end{array}$ & Medium & $\begin{array}{l}\text { Hunting } \\
\text { strategy }\end{array}$ & On vegetation & Very wet & Diurnal & Yes \\
\hline Heser nilicola & Small & Run and kill & On ground & Dry & Nocturnal & Yes \\
\hline Hogna radiata & Very large & Run and kill & On ground & Dry & Nocturnal & Yes \\
\hline $\begin{array}{l}\text { Iberina can- } \\
\quad \text { dida }\end{array}$ & Small & Trap strategy & On ground & Very dry & No preference & Yes \\
\hline $\begin{array}{l}\text { Leptodrassus } \\
\text { albidus }\end{array}$ & Small & Run and kill & On ground & Dry & Nocturnal & No \\
\hline $\begin{array}{l}\text { Leptorchestes } \\
\text { peresi }\end{array}$ & Medium & $\begin{array}{l}\text { Hunting } \\
\text { strategy }\end{array}$ & On vegetation & Dry & Diurnal & Yes \\
\hline Linyphiidae & Small & Trap strategy & On ground & Dry & No preference & Yes \\
\hline $\begin{array}{l}\text { Nemesia con- } \\
\text { gener }\end{array}$ & Very large & Trap strategy & On ground & No preference & No preference & Yes \\
\hline $\begin{array}{l}\text { Nomisia celer- } \\
\text { rima }\end{array}$ & Small & Run and kill & On ground & Dry & Diurnal & Yes \\
\hline
\end{tabular}




\begin{tabular}{|c|c|c|c|c|c|c|}
\hline Taxa & Size class & Foraging & Strate & Hygrometry & $\begin{array}{l}\text { Circadian } \\
\text { activity }\end{array}$ & Ballooning \\
\hline $\begin{array}{l}\text { Nurscia } \\
\text { albomacu- } \\
\text { lata }\end{array}$ & Medium & Trap strategy & On ground & Dry & Nocturnal & Yes \\
\hline $\begin{array}{l}\text { Oecobius } \\
\text { navus }\end{array}$ & Small & Trap strategy & On ground & No preference & No preference & Yes \\
\hline $\begin{array}{l}\text { Ozyptila beja- } \\
\quad \text { rana }\end{array}$ & Small & Sit ant wait & On vegetation & Wet & Diurnal & Yes \\
\hline $\begin{array}{l}\text { Ozyptila pul- } \\
\text { lata }\end{array}$ & Small & Sit ant wait & On vegetation & Dry & Diurnal & Yes \\
\hline $\begin{array}{l}\text { Phlegra } \\
\text { bresnieri }\end{array}$ & Medium & $\begin{array}{l}\text { Hunting } \\
\text { strategy }\end{array}$ & On vegetation & Very wet & Diurnal & Yes \\
\hline $\begin{array}{l}\text { Poecilochroa } \\
\text { albomacu- } \\
\text { lata }\end{array}$ & Medium & Run and kill & On ground & Dry & Diurnal & Yes \\
\hline $\begin{array}{l}\text { Pulchellodro- } \\
\text { mus bistigma }\end{array}$ & Small & Sit ant wait & On vegetation & Dry & Diurnal & No \\
\hline $\begin{array}{l}\text { Pulchel- } \\
\text { lodromus } \\
\text { pulchellus }\end{array}$ & Small & Sit ant wait & On vegetation & Dry & Diurnal & Yes \\
\hline Saitis barbipes & Medium & $\begin{array}{l}\text { Hunting } \\
\text { strategy }\end{array}$ & On vegetation & No preference & Diurnal & No \\
\hline Scotina celans & Small & Run and kill & On ground & Dry & Nocturnal & Yes \\
\hline $\begin{array}{l}\text { Scytodes } \\
\text { thoracica }\end{array}$ & Small & $\begin{array}{l}\text { Hunting } \\
\text { strategy }\end{array}$ & On ground & No preference & Nocturnal & Yes \\
\hline $\begin{array}{l}\text { Silhouettella } \\
\text { loricatula }\end{array}$ & Small & Run and kill & On ground & Dry & Nocturnal & Yes \\
\hline $\begin{array}{l}\text { Spermopho- } \\
\text { rides elevata }\end{array}$ & Small & Trap strategy & On ground & Dry & No preference & Yes \\
\hline $\begin{array}{l}\text { Thanatus } \\
\text { vulgaris }\end{array}$ & Medium & Sit ant wait & On vegetation & Dry & Diurnal & No \\
\hline Theridiidae & Small & Trap strategy & On vegetation & Dry & No preference & Yes \\
\hline $\begin{array}{l}\text { Trabea para- } \\
\text { doxa }\end{array}$ & Medium & Run and kill & On ground & Dry & Diurnal & Yes \\
\hline Xysticus spp. & Medium & Sit ant wait & On vegetation & Wet & Diurnal & Yes \\
\hline $\begin{array}{l}\text { Zelotes gal- } \\
\text { licus }\end{array}$ & Medium & Run and kill & On ground & Dry & Nocturnal & Yes \\
\hline Zelotes tenuis & Medium & Run and kill & On ground & Dry & Nocturnal & Yes \\
\hline Zelotes thorelli & Medium & Run and kill & On ground & Dry & Nocturnal & Yes \\
\hline $\begin{array}{r}\text { Zodarion } \\
\text { elegans }\end{array}$ & Small & Run and kill & On ground & Dry & No preference & Yes \\
\hline $\begin{array}{l}\text { Zodarion } \\
\text { timidum }\end{array}$ & Small & Run and kill & On ground & Dry & No preference & Yes \\
\hline
\end{tabular}

\section{References}

Alderweireldt M (1994) Prey selection and prey capture strategies of Linyphiid spiders in high-input agricultural fields. Bull - Br Arachnol Soc 9:300-308 
Badalamenti E, Gristina L, Laudicina VA et al (2016) The impact of Carpobrotus cfr. acinaciformis (L.) L. Bolus on soil nutrients, microbial communities structure and native plant communities in Mediterranean ecosystems. Plant Soil 409:19-34. https://doi.org/10.1007/s11104-016-2924-z

Bartomeus I, Vilà M, Santamaría L (2008) Contrasting effects of invasive plants in plant-pollinator networks. Oecologia 155:761-770. https://doi.org/10.1007/s00442-007-0946-1

Baselga A, Orme D, Villégier S et al (2018) Partitioning beta diversity into turnover and nestedness components. R package version 1.5.1. https:/CRAN.R-project.org/package=betapart. Accessed 28 Sept 2020

Bell JR, Wheater CP, Cullen WR (2001) The implications of grassland and heathland management for the conservation of spider communities: a review. J Zool 255:377-387. https://doi.org/10.1017/S0952 836901001479

Bell JR, Bohan DA, Shaw EM, Weyman GS (2005) Ballooning dispersal using silk: world fauna, phylogenies, genetics and models. Bull Entomol Res 95:69-114. https://doi.org/10.1079/BER2004350

Bergstrom DM, Lucieer A, Kiefer K et al (2009) Indirect effects of invasive species removal devastate World Heritage Island. J Appl Ecol 46:73-81. https://doi.org/10.1111/j.1365-2664.2008.01601.x

BETSI (2020) A database for soil invertebrate biological and ecological traits. https://portail.betsi.cnrs.fr. Accessed 24 Mar 2020

Blossey B (1999) Before, during and after: the need for long-term monitoring in invasive plant species management. Biol Invasions 1:301-311. https://doi.org/10.1023/A:1010084724526

Bonte D, Baert L, Maelfait J-P (2002) Spider assemblages structure and stability in a heterogeneous coastal dune system (Belgium). J Arachnol 30:331-343. https://doi.org/10.1636/01618202(2002)030[0331:SASASI]2.0.CO;2

Borchard F, Buchholz S, Helbing F, Fartmann T (2014) Carabid beetles and spiders as bioindicators for the evaluation of montane heathland restoration on former spruce forests. Biol Conserv 178:185-192. https://doi.org/10.1016/j.biocon.2014.08.006

Borges PAV, Rigal F, Ros-Prieto A, Cardoso P (2020) Increase of insular exotic arthropod diversity is a fundamental dimension of the current biodiversity crisis. Insect Conserv Divers 13:508-518. https:// doi.org/10.1111/icad.12431

Branco VV, Cardoso P (2020) An expert-based assessment of global threats and conservation measures for spiders. Glob Ecol Conserv. https://doi.org/10.1016/j.gecco.2020.e01290

Brooks ME, Kristensen K, van Benthem KJ et al (2017) glmmTMB balances speed and flexibility among packages for zero-inflated generalized linear mixed modeling. R J 9:378. https://doi.org/10.32614/ RJ-2017-066

Brown GR, Matthews IM (2016) A review of extensive variation in the design of pitfall traps and a proposal for a standard pitfall trap design for monitoring ground-active arthropod biodiversity. Ecol Evol 6:3953-3964. https://doi.org/10.1002/ece3.2176

Buchholz S (2010) Ground spider assemblages as indicators for habitat structure in inland sand ecosystems. Biodivers Conserv 19:2565-2595. https://doi.org/10.1007/s10531-010-9860-7

Buisson E, Braschi J, Chenot-Lescure J et al (2020) Native plant community recovery after Carpobrotus (ice plant) removal on an island-results of a 10-year project. Appl Veg Sci. https://doi.org/10.1111/ avsc. 12524

Campoy JG, Acosta ATR, Affre L et al (2018) Monographs of invasive plants in Europe: Carpobrotus. Bot Lett 165:440-475. https://doi.org/10.1080/23818107.2018.1487884

Celesti-Grapow L, Bassi L, Brundu G et al (2016) Plant invasions on small Mediterranean islands: an overview. Plant Biosyst 150:1119-1133. https://doi.org/10.1080/11263504.2016.1218974

Chenot J, Affre L, Gros R et al (2018) Eradication of invasive Carpobrotus sp.: effects on soil and vegetation: Carpobrotus eradication effect on soil and vegetation. Restor Ecol 26:106-113. https://doi. org/10.1111/rec. 12538

Conser C, Connor EF (2009) Assessing the residual effects of Carpobrotus edulis invasion, implications for restoration. Biol Invasions 11:349-358. https://doi.org/10.1007/s10530-008-9252-z

Cooke JAL (1965) A contribution to the biology of the British spiders belonging to the genus Dysdera. Oikos 16:20. https://doi.org/10.2307/3564861

Cristofoli S, Mahy G, Kekenbosch R, Lambeets K (2010) Spider communities as evaluation tools for wet heathland restoration. Ecol Indic 10:773-780. https://doi.org/10.1016/j.ecolind.2009.11.013

Cushing PE (2012) Spider-ant associations: an updated review of myrmecomorphy, myrmecophily, and myrmecophagy in spiders. Psyche 2012:1-23. https://doi.org/10.1155/2012/151989

D’Antonio C, Flory SL (2017) Long-term dynamics and impacts of plant invasions. J Ecol 105:1459-1461. https://doi.org/10.1111/1365-2745.12879

Deitch M, Sapundjieff M, Feirer S (2017) Characterizing precipitation variability and trends in the world's Mediterranean-climate areas. Water 9:259. https://doi.org/10.3390/w9040259 
Draney ML (1997) Diversity and life history variation among ground-dwelling Linyphiidae (Araneae). University of Georgia, Athens

Dray S, Pélissier R, Couteron P et al (2012) Community ecology in the age of multivariate multiscale spatial analysis. Ecol Monogr 82:257-275. https://doi.org/10.1890/11-1183.1

Eckert M, Gaigher R, Pryke JS, Samways MJ (2019) Rapid recovery of soil arthropod assemblages after exotic plantation tree removal from hydromorphic soils in a grassland-timber production mosaic. Restor Ecol 27:1357-1368. https://doi.org/10.1111/rec.12991

Fox J, Weisberg S (2020) An R companion to applied regression, 3rd edn. Sage, Thousand Oaks, California, USA

Gerlach J, Samways M, Pryke J (2013) Terrestrial invertebrates as bioindicators: an overview of available taxonomic groups. J Insect Conserv 17:831-850. https://doi.org/10.1007/s10841-013-9565-9

Gratton C, Denno RF (2005) Restoration of arthropod assemblages in a Spartina salt marsh following removal of the invasive plant Phragmites australis. Restor Ecol 13:358-372. https://doi.org/10.1111/ j.1526-100X.2005.00045.X

Hacala A, Le Roy M, Sawtschuk J, Pétillon J (2019) Comparative responses of spiders and plants to maritime heathland restoration. Biodivers Conserv 29:229-249. https://doi.org/10.1007/s10531-019-01880 $-\mathrm{y}$

Hedde M, Pey B, Auclerc A et al (2012) BETSI, a complete framework for studying soil invertebrate functional traits. Int Colloq Soil Zool. https://doi.org/10.13140/2.1.1286.6888

Hulme PE, Brundu G, Camarda I et al (2008) Assessing the risks to Mediterranean islands ecosystems from alien plant introductions. Backhuys Publishers, Kerkwerve, p 18

Jiménez-Valverde A, Lobo JM (2007) Determinants of local spider (Araneidae and Thomisidae) species richness on a regional scale: climate and altitude vs. habitat structure. Ecol Entomol 32:113-122. https ://doi.org/10.1111/j.1365-2311.2006.00848.x

Kettenring KM, Adams CR (2011) Lessons learned from invasive plant control experiments: a systematic review and meta-analysis: invasive plant control experiments. J Appl Ecol 48:970-979. https://doi.org/ 10.1111/j.1365-2664.2011.01979.x

Knapp DA (2014) Effects of an exotic plant invasion on arthropod assemblages. PhD Thesis, University of California

Kovoor J, Muñoz-Cuevas A (2000) Diversité des Arachnides dans les îles d'Hyères (Porquerolles et PortCros, Var, France). Modifications au cours du XXe siècle. Zoosystema 22:33-69

Krebs E, Affre L, Aboucaya A et al (2015) Résilience de la flore indigène après éradication des griffes de sorcière (Carpobrotus sp.) sur une île méditerranéenne. Revue d'Écologie (La Terre et La Vie) 70:80-90

Kremen C, Colwell RK, Erwin TL et al (1993) Terrestrial arthropod assemblages: their use in conservation planning. Conserv Biol 7:796-808

Laliberté E, Legendre P, Bill S (2014) Measuring functional diversity (FD) from multiple traits, and other tools for functional ecology. R package version 1.0-12

Le Péru B (2007) Catalogue et répartition des araignées de France. Rev Arachnol 16:1-468

Lenth R, Singmann H, Love J et al (2020) Estimated marginal means, aka least-squares means. R package version 1.4.7. https://CRAN.R-project.org/package=emmean. Accessed 24 Mar 2020

Levine JM, Vilà M, Antonio CMD et al (2003) Mechanisms underlying the impacts of exotic plant invasions. Proc R Soc Lond B 270:775-781. https://doi.org/10.1098/rspb.2003.2327

Líznarová E, Sentenská L, García LF et al (2013) Local trophic specialisation in a cosmopolitan spider (Araneae). Zoology 116:20-26. https://doi.org/10.1016/j.zool.2012.06.002

Marc P, Canard A, Ysnel F (1999) Spiders (Araneae) useful for pest limitation and bioindication. Agric Ecosyst Environ 74:229-273

Médail F (2017) The specific vulnerability of plant biodiversity and vegetation on Mediterranean islands in the face of global change. Reg Environ Change 17:1775-1790. https://doi.org/10.1007/s1011 3-017-1123-7

Moragues E, Traveset A (2005) Effect of Carpobrotus spp. on the pollination success of native plant species of the Balearic Islands. Biol Conserv 122:611-619. https://doi.org/10.1016/j.biocon.2004.09.015

Negro M, Rolando A, Barni E et al (2013) Differential responses of ground dwelling arthropods to skipiste restoration by hydroseeding. Biodivers Conserv 22:2607-2634. https://doi.org/10.1007/s1053 1-013-0544-y

Nentwig W, Blick T, Bosmans R et al (2020) Araneae version 01.2020. http://www.araneae.nmbe.ch. Accessed 24 Mar 2020

Novoa A, González L (2014) Impacts of Carpobrotus edulis (L.) N.E.Br. on the germination, establishment and survival of native plants: a clue for assessing its competitive strength. PLoS ONE 9:e107557. https ://doi.org/10.1371/journal.pone.0107557 
Novoa A, González L, Moravcová L, Pyšek P (2012) Effects of soil characteristics, allelopathy and frugivory on establishment of the invasive pant Carpobrotus edulis and a co-occuring native, Malcolmia littorea. PLoS ONE 7:e53166. https://doi.org/10.1371/journal.pone.0053166

Oger P (2020) Les araignées de Belgique et de France. https://arachno.piwigo.com. Accessed 24 Jan 2020

Oksanen J, Blanchet G, Friendly M et al (2019) Vegan: community ecology package. R package version 2.5-6. https://CRAN.R-project.org/package=vegan. Accessed 28 Sept 2020

Oliver I, Beattie AJ (1996) Invertebrate morphospecies as surrogates for species: a case study. Conserv Biol 10:99-109. https://doi.org/10.1046/j.1523-1739.1996.10010099.x

Orgeas J, Ponel P, Fadda S et al (2007) Conséquences écologiques de l'envahissement des griffes de sorcière (Carpobrotus spp.) sur les communautés d'insectes d'un îlot du Parc national de Port-Cros (Var). Sci Rep Port-Cros Natl Park 22:233-257

Palmer M, Linde M, Pons GX (2004) Correlational patterns between invertebrate species composition and the presence of an invasive plant. Acta Oecol 26:219-226. https://doi.org/10.1016/j.actao.2004.05.005

Pearce JL, Venier LA (2006) The use of ground beetles (Coleoptera: Carabidae) and spiders (Araneae) as bioindicators of sustainable forest management: a review. Ecol Indic 6:780-793. https://doi. org/10.1016/j.ecolind.2005.03.005

Pétillon J, Canard A, Ysnel F (2006) Spiders as indicators of microhabitat changes after a grass invasion in salt-marshes: synthetic results from a case study in the Mont-Saint-Michel Bay. Cah Biol Mar 47:11-18

R Development Core Team (2020) R: A language and environment for statistical computing. R Foundation for Statistical Computing, Vienna, Austria

Roberts MJ (2014) Araignées de France et d'Europe. Delachaux et Niestlé, Paris

Rodríguez J, Thompson V, Rubido-Bará M et al (2019) Herbivore accumulation on invasive alien plants increases the distribution range of generalist herbivorous insects and supports proliferation of nonnative insect pests. Biol Invasions 21:1511-1527. https://doi.org/10.1007/s10530-019-01913-1

Rodriguez-Ramirez N, Santonja M, Baldy V et al (2017) Shrub species richness decreases negative impacts of drought in a Mediterranean ecosystem. J Veg Sci 28:985-996. https://doi.org/10.1111/jvs.12558

Ruffino L, Krebs E, Passetti A et al (2015) Eradications as scientific experiments: progress in simultaneous eradications of two major invasive taxa from a Mediterranean island: Simultaneous pest eradications in the Mediterranean. Pest Manage Sci 71:189-198. https://doi.org/10.1002/ps.3786

Santoro R, Jucker T, Carranza M, Acosta A (2011) Assessing the effects of Carpobrotus invasion on coastal dune soils. Does the nature of the invaded habitat matter? Community Ecol 12:234-240. https://doi. org/10.1556/ComEc.12.2011.2.12

Saska P, van der Werf W, Hemerik L et al (2013) Temperature effects on pitfall catches of epigeal arthropods: a model and method for bias correction. J Appl Ecol 50:181-189. https://doi. org/10.1111/1365-2664.12023

Schaffers AP, Raemakers IP, Sýkora KV, ter Braak CJF (2008) Arthropod assemblages are best predicted by plant species composition. Ecology 89:782-794. https://doi.org/10.1890/07-0361.1

Skurski TC, Rew LJ, Maxwell BD (2014) Mechanisms underlying nonindigenous plant impacts: a review of recent experimental research. Invasive Plant Sci Manage 7:432-444. https://doi.org/10.1614/IPSMD-13-00099.1

Smith DiCarlo LA, DeBano SJ (2019) Spider community responses to grassland restoration: balancing trade-offs between abundance and diversity: spider community response to grassland restoration. Restor Ecol 27:210-219. https://doi.org/10.1111/rec.12832

Smith LJ, Smith DiCarlo LJ, DeBano SJ (2019) Ground crab spiders (Thomisidae: Xysticus) more abundant in grasslands invaded by cheatgrass (Bromus tectorum) and medusahead (Taeniatherum caput-medusae). Biol Invasions 21:1473-1479. https://doi.org/10.1007/s10530-019-01926-w

Uetz GW (1979) The influence of variation in litter habitats on spider communities. Oecologia 40:29-42

Uetz GW (1991) Habitat structure and spider foraging. In: Bell SS, McCoy ED, Mushinsky HR (eds) Habitat structure: the physical arrangement of objects in space. Springer, Dordrecht, pp 325-348

Uetz GW, Halaj J, Cady AB (1999) Guild structure of spiders in major crops. J Arachnol 27:270-280

Vieites-Blanco C, González-Prieto SJ (2018) Effects of Carpobrotus edulis invasion on main litter and soil characteristics in backdune and rocky coastal habitats with oceanic climate. Plant Soil 425:363-374. https://doi.org/10.1007/s11104-018-3598-5

Vilà M, Tessier M, Suehs CM et al (2006) Local and regional assessments of the impacts of plant invaders on vegetation structure and soil properties of Mediterranean islands. J Biogeogr 33:853-861. https:// doi.org/10.1111/j.1365-2699.2005.01430.x

Vilà M, Espinar JL, Hejda M et al (2011) Ecological impacts of invasive alien plants: a meta-analysis of their effects on species, communities and ecosystems. Ecol Lett 14:702-708. https://doi.org/10.111 1/j.1461-0248.2011.01628.x 
Walsh JC, Venter O, Watson JEM et al (2012) Exotic species richness and native species endemism increase the impact of exotic species on islands: impacts of exotic species on islands. Glob Ecol Biogeogr 21:841-850. https://doi.org/10.1111/j.1466-8238.2011.00724.x

Wang Y, Naumann U, Wright ST, Warton DI (2012) mvabund: statistical methods for analysing multivariate abundance data. Methods Ecol Evol 3:471-474. https://doi.org/10.1111/j.2041-210X.2012.00190.x

Warui CM, Villet MH, Young TP, Jocqué R (2005) Influence of grazing by large mammals on the spider community of a Kenyan savanna biome. J Arachnol 33:269-279. https://doi.org/10.1636/CT05-43.1

Whittaker RJ, Fernández-Palacios JM, Matthews TJ et al (2017) Island biogeography: Taking the long view of nature's laboratories. Science 357:eaam8326. https://doi.org/10.1126/science.aam8326

Wise DH (1993) Spiders in ecological webs. Cambridge University Press, Cambridge

Woodcock BA (2005) Pitfall trapping in ecological studies. In: Leather SR (ed) Insect sampling in forest ecosystems. Blackwell Science Ltd, Oxford, pp 37-57

Zavaleta ES, Hobbs RJ, Mooney HA (2001) Viewing invasive species removal in a whole-ecosystem context. Trends Ecol Evol 16:454-459. https://doi.org/10.1016/S0169-5347(01)02194-2

\section{Affiliations}

\section{Julie Braschi $^{1,2,3} \cdot$ Ophélie Hélard $^{1} \cdot$ Christophe Mazzia $^{1} \cdot$ Pierre Oger $^{4}$. Philippe Ponel $^{1}$ (D). Elise Buisson ${ }^{1,3}$}

1 Institut Méditerranéen de Biodiversité et d'Ecologie marine et Continentale, Aix-Marseille Université, Avignon Université, CNRS, IRD, Marseille, France

2 Naturalia Environnement, Agence d'Avignon - Site Agroparc. 20, rue Lawrence Durrell, BP 31 285, 84911 Avignon cedex 9, France

3 Department of Plant Sciences, University of California, Davis, CA 95616, USA

4 Waret-l'Evêque 4217, Belgium 